\title{
Current Situation and Suggestions of Mental Health Service System in Universities
}

\author{
Chen Benyou \\ Psychology and Social Development Research Center, Southwest University, Chongqing, China \\ Email: chbenyou@swu.edu.cn
}

Received 8 October 2014; revised 11 November 2014; accepted 19 November 2014

Academic Editor: Shaodan Luo, Wuhan Irvine Culture and Communications, China

Copyright (C) 2014 by author and Scientific Research Publishing Inc.

This work is licensed under the Creative Commons Attribution International License (CC BY). http://creativecommons.org/licenses/by/4.0/

c) (i) Open Access

\begin{abstract}
Mental health service is an important system. An investigation of 257 employees leads to the following conclusions. 1) The overall situation of mental health service system in universities remains well $(M=3.62)$ after management training $(M=2.85)$. 2) There are significant differences in the second-level indicators of service effects in mental health service system. 3) There are significant differences between genders and among service providers in universities. The paper concludes that the mental health service system oriented to mental promotion and student-centered principle should be established in universities to improve the mental health service.
\end{abstract}

\section{Keywords}

Mental Health, Mental Health Service System, Colleges, Universities

\section{Introduction}

Mental health service system is composed of specialized agencies, personnel, etc. (Huang Xiting et al., 2007). In recent years, despite the rapid development of the mental health service system, mental health problems are still worried by the public. As SCL-90 scale shows, the level of college students' mental health is generally lower than that of social youths of the same age (Ma Li \& Liu Wei, 2008). As the self-compiled questionnaire indicates, university students have problems in emotion management, interpersonal communication, stress, etc. (Wu Yan, 2012; Liu Hong, 2012). According to the questionnaire on students’ need for mental-health service, university students pay close attention to their relationships and studies, etc. (Huang Xiting et al., 2011). Besides, there are some serious issues to be solved in mental management, which, for instance, requires urgent settlement in technology system, practitioners, education management and supervision, qualification, etc. (Huang Xiting et 
al., 2007; Wang Lin, 2008). In contrast, the system of mental-health service in some developed countries is relatively complete. It provides a reference for the Chinese mental health service in universities (Fan Fumin \& Ji Yuanhong, 2008; Xu Huachun \& Huang Xiting, 2007).

As a comprehensive engineering, the promotion of mental health calls for effective implementation and coordination of work in mental-health service system. Thus, it is necessary to develop related theories and conduct empirical research. However, the service system of mental health in universities still weak in empirical analysis in spite of its strengths in theorizations. Based on the theoretical framework, which includes mental promotion, Institution Building, Management Training, etc. (Huang Xiting et al., 2007; Wang Lin, 2008), this paper reports on an empirical investigation with an analysis of the current situation of the system of mental-health service in Chinese universities.

\section{Methods}

\subsection{Survey Tools}

Using relevant Chinese and other literatures, scales on mental health service system, and an open-ended questionnaire, this study analyzes the service system of mental health in 10 Chinese universities. It divides the measures for mental promotion into five first-level dimensions and ten second-level dimensions with respect to psychological promotion, institution-building, resource allocation, system construction, and management training. On this basis, the rating scores in the initial questionnaire can be classified into five levels, where "1" stands for totally inconsistency and "5" stands for totally coincidence. Then in line with the questionnaire requirements, each item is scored on the basis of compliance degree. Factors of 430 initial tests are analyzed. Among them 230 are for exploratory factor analysis and 200 tests for confirmatory factor analysis. In the exploratory factor analysis of 230 tests, 5 first-level dimensions cumulative explain the $49.512 \%$ of amount of variability. In the confirmatory factor analysis of 200 tests, the questionnaire structure is highly accordant with theoretical conception. The Cronbach of the entire questionnaire and those at all dimensions is 0.792 , and the Guttmamn is 0.783 . These data, therefore, meet the surveying requirements. Consequently, the final questionnaire, including 26 items, on the service system of mental health in universities is established.

\subsection{Respondents}

The respondents come from 10 universities in southwestern China, including six national key universities (three "985 engineering" universities and three "211 engineering" universities), four provincial key universities, and three local general colleges. And they are mostly engaged in mental health services or education. Questionnaires add up to 300. Among the 276 valid questionnaires, 276 from 124 male respondents and 152 are from female ones. Each item in a questionnaire is rated from 1 to 5 levels, according to the rating method.

\section{Results and Analysis}

\subsection{General Characteristics of Service System of Mental Health in Universities}

\subsubsection{General Characteristics}

The score of each first-level dimension in mental health service system is shown as Table 1.

As Table 1 shows, the overall current situation of service system of mental health is good $(\mathrm{M}=3.69)$ in universities. The services effect of mental promotion is fine $(M=3.62)$. However, the corresponding safeguard measures score unevenly. Specifically, the institutional settings and improvement are relatively sound but it needs to be strengthened in management training $(M=2.85)$. As the correlation coefficients in Table 2 indicate, there are significant differences between mental promotion and other safeguard factors. Except for the management training, other indicators contribute to the mental promotion. Consequently, the unbalance of the service fails to make significant mental promotion.

\subsubsection{Current Characteristics of Each Factor of Mental Health Services}

The statistics and difference tests of the second-level dimensions in mental health service system are shown in Table 3.

As Table 3 shows, the mean values of second-level dimensions in mental health service system in universities 
Table 1. Overall current situation of service system of mental health $(\mathrm{N}=276)$.

\begin{tabular}{ccccccc}
\hline & $\begin{array}{c}\text { Mental } \\
\text { Promotion }\end{array}$ & $\begin{array}{c}\text { Institution } \\
\text { Building }\end{array}$ & $\begin{array}{c}\text { Resource } \\
\text { Allocation }\end{array}$ & $\begin{array}{c}\text { Institutional } \\
\text { Improvement }\end{array}$ & $\begin{array}{c}\text { Management } \\
\text { Training }\end{array}$ & Total \\
\hline$M$ & 3.62 & 4.14 & 3.78 & 4.08 & 2.85 & 3.69 \\
$S D$ & 0.62 & 0.56 & 0.53 & 0.48 & 0.58 & 0.60 \\
\hline
\end{tabular}

Table 2. Correlation coefficient of mental promotion and various safeguard factors.

\begin{tabular}{cccc}
\hline & Institution Building & Resources Allocation & Institutional Improvement \\
\hline Mental Promotion & $0.38^{* *}$ & $0.26^{*}$ & $0.32^{* *}$ \\
\hline Note: ${ }^{* *} P<0.01,{ }^{*} P<0.05$ & & & 0.17 \\
\hline
\end{tabular}

Table 3. Overall situation and difference tests of various indicators in mental health service system.

\begin{tabular}{|c|c|c|c|c|c|c|c|c|c|c|}
\hline & \multicolumn{2}{|c|}{ Mental Promotion } & \multicolumn{2}{|c|}{ Institution Building } & \multicolumn{2}{|c|}{ Resources Allocation } & \multicolumn{2}{|c|}{$\begin{array}{l}\text { Institution } \\
\text { Improvement }\end{array}$} & \multicolumn{2}{|c|}{ Management Training } \\
\hline & $\begin{array}{l}\text { Education } \\
\text { Promotion }\end{array}$ & $\begin{array}{l}\text { Counseling } \\
\text { Intervention }\end{array}$ & $\begin{array}{c}\text { Functional } \\
\text { Establishment }\end{array}$ & $\begin{array}{c}\text { Service } \\
\text { Measures }\end{array}$ & $\begin{array}{l}\text { Hardware } \\
\text { Facilities }\end{array}$ & $\begin{array}{l}\text { Software } \\
\text { Facilities }\end{array}$ & $\begin{array}{c}\text { Policy } \\
\text { Specification }\end{array}$ & Ethics & $\begin{array}{l}\text { Supervision } \\
\text { Mechanism }\end{array}$ & $\begin{array}{c}\text { Personal } \\
\text { Qualifications }\end{array}$ \\
\hline$M$ & 4.02. & 3.22 & 4.21 & 4.07 & 3.87 & 3.69 & 4.10 & 4.02 & 2.12 & 3.58 \\
\hline$S D$ & 0.64 & 0.58 & 0.51 & 0.56 & 0.58 & 0.60 & 0.52 & 0.56 & 0.61 & 0.55 \\
\hline $\mathrm{t}$ & \multicolumn{2}{|c|}{$2.103^{* *}$} & \multicolumn{2}{|c|}{$1.892^{*}$} & \multicolumn{2}{|c|}{1.035} & \multicolumn{2}{|l|}{1.357} & \multicolumn{2}{|c|}{$2.683^{* *}$} \\
\hline
\end{tabular}

are different from each other. In terms of the mental promotion, the item of education promotion is higher than that of counseling intervention $(P<0.01)$. That is, the former work is better the latter. As for the institutionbuilding, the item of functional establishment scores much higher than the service measures, where $P<0.05$. In terms of the resources allocation, there are no marked differences between software and hardware facilities, neither are the policy specification and ethics in institution building. And in terms of the management training, the supervision mechanism is dramatically lower than the personal qualifications $(P<0.01)$, which indicates the need for regulatory mechanisms in mental health service. Generally speaking, this indicates an urgent need to further improve the service system of mental health in universities. The students still have serious problems in terms of mental health, such as the lack of complete mental service.

\subsection{Specific Characteristics of Mental Health Service System in Universities}

\subsubsection{Demographic Multivariate Analysis of Mental Promotion}

The mental promotion plays an important role in the service system of mental health. Shown in Table 4 is the result of our t tests of independent samples on gender-related differences and their correlation with types of universities. In the tests, significant differences and correlations are identified with regard to mental promotion. Specifically, the performance of the female is much better than that of the male $(P<0.01)$. The working of national key college is significantly superior to that of provincial key college $(P<0.05)$ and general college $(P<$ 0.01). The performance of provincial key college is much better than that of general college $(P<0.05)$.

Besides, both the training experience and professional background affect the effective execution of mental promotion. As for our variance analysis of both factors, there are exactly as the result shows remarkable main effects in training experience $(\mathrm{F}(1276)=3.86, P<0.05)$, professional background $(\mathrm{F}(1276)=5.24, P<0.01)$, and the interaction effect $(\mathrm{F}(1276)=2.75, P<0.05)$. Further, the mental promotion operated with psychology professional background is superior to the one without related background $(\mathrm{F}(1138)=4.03, P<0.01)$ on the premise of the training experience of personnel.

\subsubsection{Analysis of Serious Issues in Mental Health Service}

According to the analysis above, the item of management training scores the lowest $(\mathrm{M}=2.85)$ among all the items of mental health service. It indicates serious issues in mental health service. Further analysis of all the items has been conducted in order to figure out the problems. Its result, shows that the items of "monitoring of service status”, “certification”, and "performance evaluation” with score below three respectively occupy the 
Table 4. Difference tests on gender and colleges in mental promotion (t).

\begin{tabular}{ccccccc}
\hline & \multicolumn{2}{c}{ Gender } & \multicolumn{2}{c}{ Colleges } \\
\cline { 3 - 7 } & & Male (124) & Female (152) & National Key College & Provincial key College & General College \\
\hline \multirow{2}{*}{ Mental Promotion } & $M$ & 3.18 & 4.06 & 3.98 & 3.64 & 3.24 \\
\cline { 3 - 7 } & $S D$ & 0.67 & 0.48 & 0.61 & 0.59 & 0.65 \\
\hline
\end{tabular}

Note: a, b, c stand for the value t between national and provincial key college, the one between national key and general college, the one between provincial key and general college.

proportion of $71.2 \%, 66.5 \%$, and $61.3 \%$ in supervision mechanism. The lower the college is in status, the higher the proportion will be. In terms of personal qualification, the proportion of the personnel without training experience reaches $64.6 \%$ in key colleges, and the proportion of personnel with psychology professional background reaches $74.8 \%$ in key colleges. General colleges claim only 37.2\% in this regard. However, all the personnel involved in mental service in universities are equipped with counselor certificate. As a result, it will be difficult to carry out mental health services effectively for the lack of effective supervision mechanism and high-level personnel qualifications. Therefore, the mental health of college students needs to be improved.

\section{Suggestions}

Based on the results above, the following suggestions are made for the improvement of the mental health service system in universities.

It is important to establish a service system of mental health service system aimed at mental promotion. Due to the poor effect of mental health promotion in universities, related personnel in universities should have a better understanding of the service system of mental health. Mental promotion targets on the mental health services and other four items play various supporting roles in the service. They work together to optimize students' mental health. Once some items are neglected, the central goal will be affected and the effectiveness of the system will be weakened.

There should definitely be student-oriented concept of mental health service. Service concept in universities should be adjusted for the sake of weak central goal (mental promotion) and excessive security conditions, including institution-building, resource allocation, and institutional improvement. Then we should focus on the improvement of students' mental health in universities as well as other related safeguard issues, especially the service measures involving personnel, students and practitioners in management training. Consequently, it will improve the services effect of safeguard factors if excess use of resources and loss of system effectiveness are prevented. Mental health services in developed countries are centered on students (Manderscheid et al., 2000). And they have also made their contributions to Chinese service system of mental health in universities.

Universities should recognize the importance of the mental health promotion and improve the selection system of employees. As the survey result shows, the effects of mental health promotion differ in terms of genders, certifications, training experiences, and practitioners' professional background during the process of service promotion. First of all, high standard should be maintained for practitioners' qualifications. Second, gender advantages should be taken into account. For instance, females outperform males in language ability and empathy communication. Finally, we must strengthen the job training of practitioners and normalize the certification qualifications in order to satisfy the psychological demands of students, strengthening the employees' quality, and ensure high efficiency of the system.

And there need to be improvements in the mental health services of local general colleges, especially in the aspect of management training. As the survey result of the investigated colleges indicates, the system of mentalhealth service in general colleges requires more improvements and supervision. It will be harmful to the society if a student is poor in psychology in spite of his or her outstanding professional qualities. For the general colleges, it is urgent to strengthen the professional development and their mental health service, so as to educate talents for the society.

\section{Acknowledgements}

This research project is sponsored by Chongqing Humanistic and Social Science focused research study base: 
Study on the current situation and countermeasures of mental health service system in colleges and universities of southwest China (09KB25).

\section{References}

Fan Fumin 焚富民, \& Ji Yuanhong 吉沅洪 (2008). Riben xinli jiankang fuwu tixi peixun yu guanli de xianzhuang ji fazhan qushi 日本心理健康服务体系培训与管理的现状及发展趋势 [Status and Development Trend on Training and Management of Mental Health Service System in Japan]. Zhongguo Linchuang Xinlixue Zazhi, 22, 588-589.

Huang, Xiting 黄希庭, Zheng Yong 郑涌, Bi Zhongzeng 毕重增, \& Chen Youzhen 陈幼贞 (2007). Guanyu zhongguo xinli jiankang fuwu tixi jianshe de ruogan wenti 关于中国心理健康服务体系建设的若干问题 [Several Issues on the Improvement of Mental Health Service System in China]. Xili Кехие, 30, 2-5.

Huang Xiting 黄希庭, Zheng Yong 郑涌, Luo Mingchun 罗鸣春, Su Dan 苏丹, \& Chen Benyou 陈本友 (2011). Zhongguo daxuesh xinli jiankang fuwu xuyao diaocha yu pinggu 中国大学生心理健康服务需要调查与评估 [Mental Health Services of Chinese College Students Requires Survey and Assessment]. Xinan Daxue Xuebao (Shehui Kexue Ban), 37, $1-5$.

Liu Hong 刘虹 (2012).Gaoxiao daxuesheng xinli jiankang xianzhuang diaocha ji duice yanjiu 高校大学生心理健康现状 调查及对策研究 [Situation and Countermeasures of Mental Health of College Students]. Changsha Tiedao Xueyuan Xuebao (Shekeban), 13, 219-221.

Ma Li 马利, \& Liu Wei 刘巍 (2008). 10 nianlai zhongguo daxuesheng xinli jiankang diaocha jieguo de meta fenxi 10 年来 中国大学生心理健康调查结果的 meta 分析 [Meta Analysis on Survey Results of Mental Health of Chinese College Students in Recent 10 Years]. Zhongguo Xinli Weisheng Tongji, 25, 289-290.

Manderscheid, R. W., Henderson, M. J., Witkin, M. J. et al. (2000). The US Mental Health System of the 1990s: The Challenges of Managed Care. International Journal of Law and Psychiatry, 23, 245-259.

Xu Huachun 徐华春, \& Huang Xiting 黄希庭(2007). Guowai xinli jiankang fuwu jiqi qishi 国外心理健康服务及其启示 [Mental Health Services Abroad and Its Inspiration]. Xinli Kexue, 30, 1006-1009.

Wang Lin 王琳 (2008). Chongqingshi gaoxiao xinli jiankang fuwu tixi de xianzhuang diaocha 重庆市高校心理健康服务 体系的现状调查 [Survey of Mental Health Service System of Universities in Chongqing]. Xinan Daxue Shuoshi Xuewei Lunwen [Master Thesis of Southwestern University], Chongqing: Xinan Daxue.

Wu Yan 武艳 (2012). Gaozhi yuanxiao daxuesheng xinli jiankang xianzhuang yu duice 高职院校大学生心理健康现状及 对策 [Situation and Countermeasures of Mental Health of Vocational College Students]. Shanxi Shida Xuebao (Shekeban), S4, 157-159. 
Scientific Research Publishing (SCIRP) is one of the largest Open Access journal publishers. It is currently publishing more than 200 open access, online, peer-reviewed journals covering a wide range of academic disciplines. SCIRP serves the worldwide academic communities and contributes to the progress and application of science with its publication.

Other selected journals from SCIRP are listed as below. Submit your manuscript to us via either submit@scirp.org or Online Submission Portal.
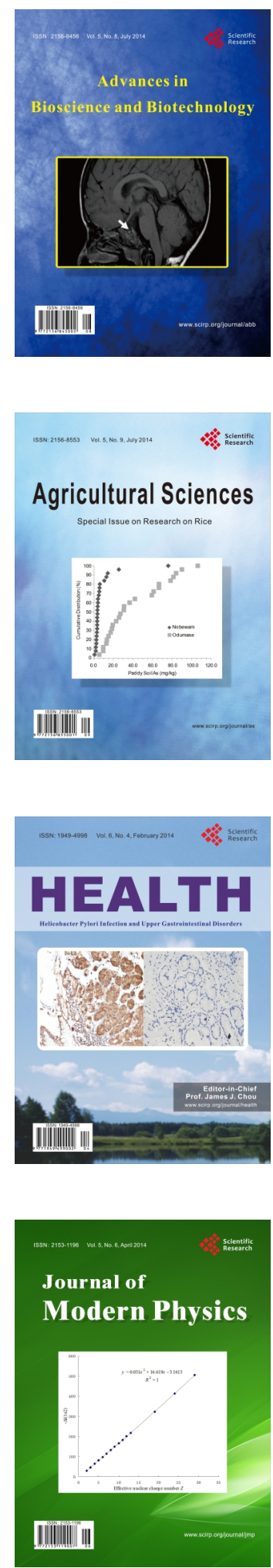
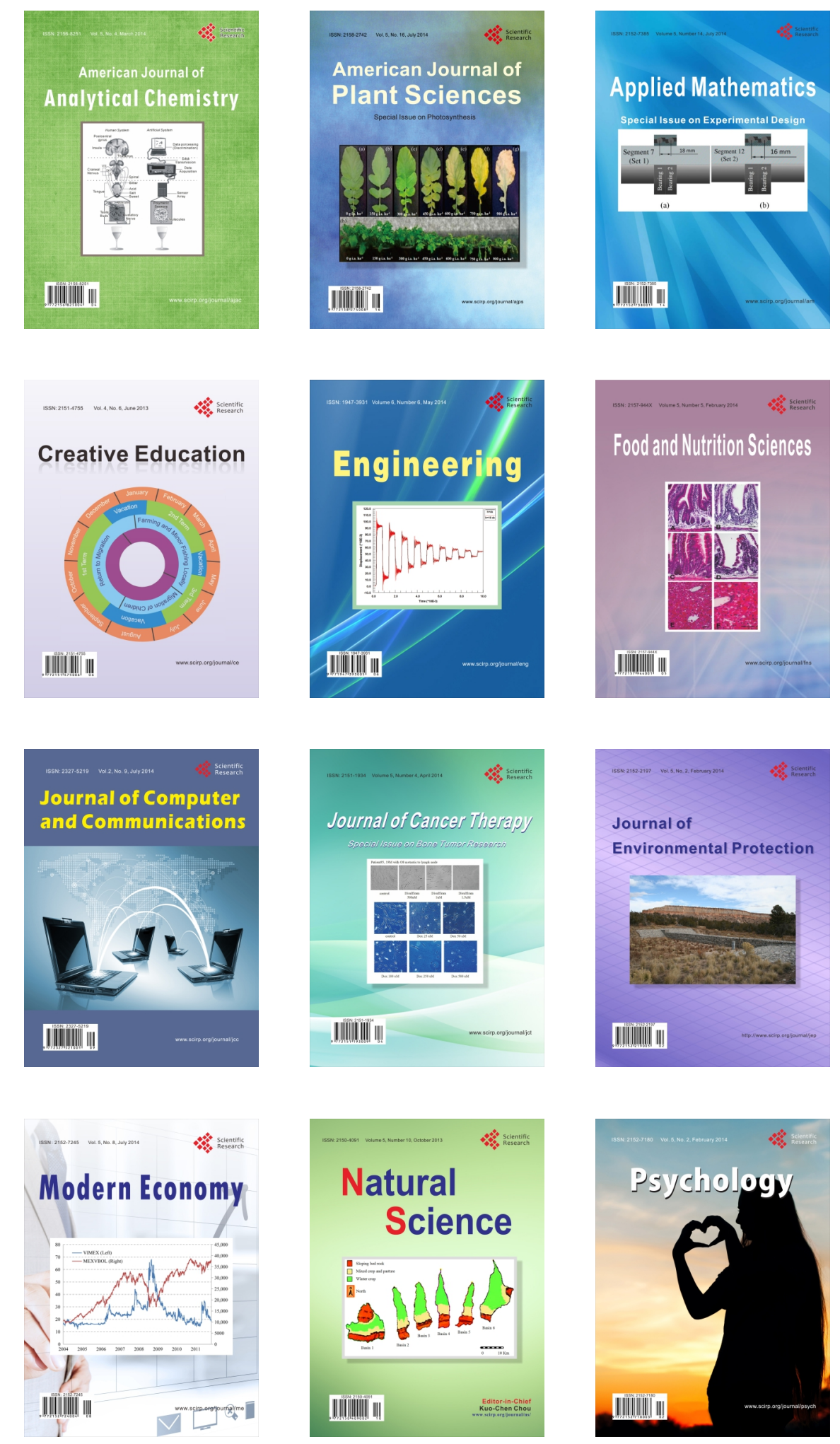